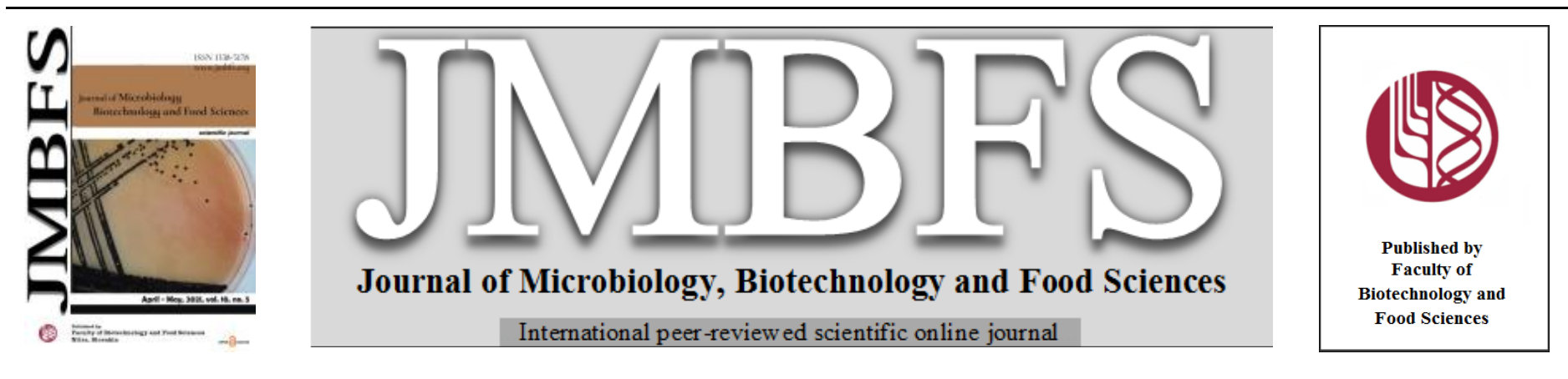

\title{
MICROARRAY-BASED ANALYSIS OF STAPHYLOCOCCUS AUREUS ISOLATES FROM NON-CLINICAL SOURCE
}

\author{
Asabe Halimat Momoh-Zekeri*1, Jacob Kwaga ${ }^{2}$, Mohammed Bello $^{2}$, Anthony Sackey ${ }^{3}$
}

Address(es): Dr Asabe Halimat Momoh-Zekeri,

${ }^{1}$ Federal University of Jos, Faculty of Veterinary Medicine, Department of Veterinary Microbiology and Pathology, PMB 2084, Jos, Plateau State, Nigeria. $+2348038352906$

${ }^{2}$ Ahmadu Bello University, Faculty of Veterinary Medicine, Department of Veterinary Public Health and Preventive Medicine, PMB 1044, Zaria, Kaduna State, Nigeria.

${ }^{3}$ Ahmadu Bello University, Faculty of Veterinary Medicine, Department of Veterinary Medicine, PMB 1044, Zaria, Kaduna State, Nigeria.

*Corresponding author: momohh@unijos.edu.ng

https://doi.org/10.15414/jmbfs.3194

ARTICLE INFO

Received 29. 5. 2020

Revised 30. 11. 2020

Accepted 4. 12. 2020

Published 1. 4. 2021

Regular article

open $\partial_{\text {AcCESS }}$

\begin{abstract}
This study was aimed to genotyped virulence, toxin and resistance genes of $30 \mathrm{~S}$. aureus isolates from pigs using DNA microarray. The 30 isolates analyzed in this study all belonged to clonal complexes (CC) CC1 $(3 ; 10 \%)$, CC5 (3; 10\%), CC15 (16; $53.33 \%)$ and CC152 $(8 ; 26.66 \%)$, respectively. Of antibiotic resistance-associated genes reported; Twenty out of 30 isolates $(66.66 \%)$ carried the betalactamase operon $($ blaZ/I/R) and the tetracycline resistance gene (tet K), respectively. Also, the macrolide resistance gene (ermA $/ \mathrm{msr} A)$ were detected in ten isolates (33.33\%), the multidrug efflux pump resistance gene ( $s d r M$ ) was detected in seven isolates $(23.33 \%)$ and one isolates (3.33\%) harboured the chloramphenicol resistance gene (cat). None of the isolates harboured genes conferring methicillin resistance. In terms of genes encoding enterotoxins; $s e b$ was detected among all isolates of $\mathrm{CC} 15$ while the enterotoxin gene cluster $e g c$ and a distinct variant of the enterotoxin A (sea-N315) were detected among isolates of CC5 and CC152, respectively. Two CC152 isolate was positive for genes encoding the Panton-Valentine leukocidin $(l u k F-P V+l u k S-P V)$. In addition, all the isolates harboured the genes encoding for intracellular adhesion proteins $(i c a \mathrm{~A} / \mathrm{C} / \mathrm{D})$ and the biofilm-associated genes $(c l f \mathrm{~A}$ and $c l f \mathrm{~B})$ except for $\mathrm{CC} 1$ isolates. The capsular genes cap 5 and cap 8 were detected in isolates of CC5 and CC15 while only cap 5 was present in CC152 isolates. The study provides detailed genotyping data on the population structure, presence of toxins and antibiotic resistance markers of $S$. aureus isolates and indicates the importance of the microarray technique in analyzing multiple gene contents of bacteria.
\end{abstract}

Keywords: Staphylococcus aureus; Animals; Pigs; DNA-Microarray; Virulence genes

\section{INTRODUCTION}

S. aureus is a well-known colonizer of human population as well as livestock and domestic animals worldwide (Eko et al., 2015). In humans, it causes a wide range of infections ranging from mild to life threatening diseases (Bazzi et al., 2015). Some animal strains of $S$. aureus have been reported to be zoonotic (Monecke et al., 2011), as a result of its association with pigs and people who work in close contact with animals. It is however not well understood which factors are responsible for host specific behaviour in $S$. aureus (Gordon et al. 2008). In humans, the success of $S$. aureus as a pathogen is partly due to its ability to express a variety of virulence factors that mediate host colonization, tissue invasion and dissemination (Sabat et al., 2013).

There is paucity of data on the host specific virulence factor for animals. Many animal species are known to be colonized or infected by $S$. aureus but of all livestock, pigs appear to be the most implicated. However, due to lack of typing data, it is not known whether isolates of animal origin harbour their own host specific strains or promiscuous strains with zoonotic potentials (Monecke et al., 2011). Hence, it is of great interest to systematically genotype the $S$. aureus isolates from pigs considering that they are important food animals with considerable contact with humans especially those occupationally exposed.

In Nigeria and sub-Saharan Africa at large, identification of bacterial pathogens is still limited to phenotypic methods which lacks the ability to give an in-depth analysis of the pathogen. The identification of bacterial clones with enhanced virulence or increased ability to spread is therefore important. Hence, DNA based micro-array analysis used in this study is a rapid method for analyzing the gene contents of a pathogen. It can simultaneously analyse the antimicrobial resistance and virulence gene content of $S$. aureus (Sabat et al., 2013) and even other pathogens.

In order to obtain an insight into the population structure of S. aureus in pigs at slaughter, a collection of isolates originating from an abattoir were genotyped using microarray.

\section{MATERIALS AND METHODS}

\section{Sample collection, Isolates and culture}

Thirty (30) S. aureus isolates from the pig section of an abattoir were analysed in this study. In brief, sterile swabs were used to collect nasal samples from 100 pigs for a period of 2 months. Sampled animals originated from farms, and all pigs sampled were adult pigs. All samples were placed on ice following collection and processed within $24 \mathrm{~h}$. The samples were inoculated into $5 \mathrm{ml}$ Brain-heart infusion broth (Oxoid) containing 6.5\% $\mathrm{NaCl}$ for enrichment and incubated for $24 \mathrm{~h}$ at $37^{\circ} \mathrm{C}$. Preliminary verification of $S$. aureus was based on colony characteristics on Baird Parker agar (Oxoid) supplemented with egg yolk tellurite, Sheep blood agar, and positive results for catalase, coagulase and DNase tests. The isolates were further confirmed by matrix-assisted laser desorption/ionization-time of flight mass spectrometry (MALDI-TOF MS) and antibiotic sensitivity to cefoxitin (30 $\mu \mathrm{g}$, Oxoid) and oxacillin $(1 \mu \mathrm{g}$, Oxoid) discs were performed using the Kirby Bauer disc diffusion method (Bauer et al., 1966) on Mueller Hinton media.

\section{Microarray Procedures}

S. aureus genomic DNA was extracted from an 18-24 hour old culture on sheep blood agar using lysis buffer and lysis enhancer (StaphyType Kit, Alere Technologies GmbH, Jena, Germany). DNA microarray analysis was carried out as described by the manufacturer. The microarray kit covers 334 target sequences including $S$. aureus species markers, resistance associated genes, genes encoding SEs and enterotoxin-like proteins, accessory gene regulator, capsule and biofilm-associated markers, and a variety of other genes. Resulting DNA microarray profiles were grouped to various clonal complexes (CCs) by the imaging software Iconoclust based on comparison of hybridization profiles to a 
collection of reference strains previously characterized by multilocus sequence testing (MLST)

\section{RESULTS}

\section{Antibiotic Resistance-associated and enterotoxin genes}

All of the 30 isolates were phenotypically susceptible to cefoxitin (inhibition zone $\geq 22 \mathrm{~mm}$ ) and oxacillin (inhibition zone $\geq 13 \mathrm{~mm}$ ) and the $m e c A$ gene was also not detected hence there were no MRSA among the tested isolates. Amongst all the resistance-associated genes tested, the beta-lactamase operon (blaZ/R/I) and the tetracycline genes (tet $K$ ) were detected among twenty $(66.66 \%)$ isolates respectively. Furthermore, macrolide genes ( $\mathrm{ermA} / \mathrm{msrA})$ were present in ten $(33.33 \%)$ isolates while only one of the 30 isolates $(3.33 \%)$ carried the chloramphenicol gene (cat) while seven isolates $(23.31 \%)$ carried the $s d r M$ (a multidrug efflux pump). Based on the genes encoding staphylococcal enterotoxins (SE) and enterotoxin-like proteins, twenty $(66.66 \%)$ isolates harboured the sea, seb and the enterotoxin gene cluster egc (seg, sei, selm, seln, selo, selu).

\section{Representation of Clonal complex}

The 30 isolates were assigned to 4 Clonal Complexes (CC). Of the 30 isolates, 16 $(53.33 \%)$ belonged to $\mathrm{CC} 15,8(26.66 \%)$ isolates belonged to $\mathrm{CC} 152$ and while 6 (20\%) isolates three each belonged to $\mathrm{CC} 1$ and $\mathrm{CC} 5$, respectively. All the isolates belonging to $\mathrm{CC} 15$ were positive for seb whereas isolates CC152 and CC5 harboured the enterotoxin cluster $e g c$ and enterotoxin A alleles (sea, sea-N315), respectively. Isolates belonging to $\mathrm{CC} 5$ and $\mathrm{CC} 15$ carried the sasG, $s d r \mathrm{C} s d r \mathrm{D}$ genes. These isolates also showed positive hybridization to agr group II and harboured both capsule type 5 and capsule type 8 .

The second most common clonal complex was CC152 (8; 26.66\%). These isolates carried the $s c n, s d r \mathrm{D}$, capsule type 5 , cna but lacked $s a G$ gene. The Panton-Valentine leukocidin genes $(l u k F-P V+l u k S-P V)$ were present in two $\mathrm{CC} 152$ isolates. Isolates $\mathrm{CC} 5, \mathrm{CC} 15$ and $\mathrm{CC} 152$ all harboured genes for intracellular adhesion proteins (icaA, icaC, icaD).

Finally, all CC-groups were found to be positive for the beta lactamase operon and tetK except for CC5 that only harboured tet $\mathrm{K}$. Two isolates of $\mathrm{CC} 1$ and five isolates of $\mathrm{CC} 15$ harboured the $s d r M$ (multidrug efflux pump gene) respectively. Also, all isolates except isolates belonging to CC1 carried clfA, clfB as well as $i c a A$, icaC, icaD. CCI did not harbour any capsular and enterotoxin genes.

Table 1 Analysis of $30 \mathrm{~S}$. aureus isolates recovered from pigs at slaughter: assigned clonal complexes, spa types, presence of genes encoding antibiotic resistance, staphylococcal enterotoxins and enterotoxin-like proteins, capsule and biofilm-associated markers

\begin{tabular}{|c|c|c|c|c|}
\hline $\begin{array}{l}\text { No of } \\
\text { Isolates }\end{array}$ & $\begin{array}{l}\text { Clonal } \\
\text { Complexes }\end{array}$ & $\begin{array}{c}\text { Antibiotic Resistant-associated } \\
\text { genes }\end{array}$ & $\begin{array}{l}\text { Genes encoding enterotoxins } \\
\text { and virulence }\end{array}$ & $\begin{array}{l}\text { Capsule and Biofilm-associated } \\
\text { accessory gene regulator } \\
\text { and adhesion genes }\end{array}$ \\
\hline 16 & $\mathrm{CC} 15$ & blaZ/I/R, tetK, fosB, sdrM (5) & seb & $\begin{array}{c}\text { Sas } G, \text { sdrC, sdrD, agrII, cap } 5, \text { cap } 8, \\
\text { icaA/C/D, clfA, clfB }\end{array}$ \\
\hline 8 & $\mathrm{CC} 152$ & blaZ/I/R, tetK, ermA/msrA (2) & $\begin{array}{l}\text { (egc) seg/sei/selm/seln/selo/selu, } \\
\text { sea-N31, lukD+lukE (2), scn, cna, }\end{array}$ & cap5, sdrD, icaA/C/D, clfA, clfB \\
\hline 3 & $\mathrm{CC} 1$ & blaZ/I/R, tetK, sdrM (2) & N.D & N.D \\
\hline 3 & CC5 & blaZ/I/R, tetK, cat (1) & $\begin{array}{c}\text { (egc) } \mathrm{seg} / \mathrm{sei} / \mathrm{selm} / \mathrm{seln} / \mathrm{selo} / \mathrm{selu}, \\
\text { sea } \mathrm{N} 315\end{array}$ & $\begin{array}{c}\text { sas } G, s d r C, s d r D, \text { agrII, cap } 5, \text { cap } 8, \\
i c a A / C / D, \text { clfA, clfB }\end{array}$ \\
\hline
\end{tabular}

\section{DISCUSSION}

This study gives a first insight into the population structure and the presence of resistance and virulence-associated genes of $S$. aureus isolates of pig origin. In total, there were no MRSA among the tested 30 isolates. This finding corroborates the fact that there are very scanty reports on MRSA in animals in Nigeria and Africa at large. The presence of $b l a Z / R / I$ and $t e t K$ genes is not surprising considering the intensive use of these antimicrobials in livestock production as they are relatively cheap drugs and readily available over the counter for purchase without prescription (Momoh et al., 2018; Adesokan et al. 2015). The presence of $\operatorname{ermA} / \mathrm{msrA}$ (macrolide resistance) genes among these isolates is worrisome as these genes are reported to be widely distributed in staphylococci of human origin and they are plasmid borne (Shaker et al., 2014) This finding is of public health importance due to their capability of horizontal gene transfer between species and genera (Svara and Rankin, 2011).

Interestingly, CC5 has so far been reported as the predominant CC-group observed among pigs (Monecke et al., 2011; He et al., 2013; Frana et al., 2013; Smith et al., 2013) while $\mathrm{CC} 15$ and $\mathrm{CC} 152$ have been reported to be the prevailing CC-group among clinical isolates associated with bacteremia in Ghana and Nigeria, respectively (Egyir et al., 2013; Shittu et al., 2012) and in China (Frana et al., 2013). Also, Fall et al. (2012) reported the presence of CC15 and CC152 among pigs in Dakar while Song et al. (2015) reported CC5 among raw and processed food in Shanghai. Among the isolates, CC15 and CC152 were the most predominant in this study. Similar results have been reported by Breurec et al. (2011) and Shittu et al. (2012) from other studies on the molecular structure of African MSSA.

Genes associated with enterotoxins are very important and little is known about enterotoxigenic $S$. aureus from pigs. The presence of genes encoding classical SEs in most of the $S$. aureus isolates in this study is interesting considering the fact that these SEs reported in this study are known to induce emetic reaction which imply their role in staphylococcal poisoning and they have also been reported among other animals and humans. In most of the pig isolates in this study, genotype-enterotoxin association was similar to that known from human $S$. aureus isolates. This report is in tandem with the report of Bryston et al. (2015) who reported $S$. aureus isolates harbouring genes encoding emetic SEs in pork and pigs in Poland.

The accessory gene regulator ( $a g r)$ and capsule typing methods are importan tools for the characterization of $S$. aureus (Goerke et al. 2005). All the isolates showed positive hybridization to agrII. The higher incidence of agrII may be associated with the virulence potential of $S$. aureus (Cheung et al., 2011). This observation is in agreement with the report of Song et al. (2015) who reported that agr-type identified is important among $S$. aureus strains as this locus regulates the synthesis of virulence determinants. DNA microarray analysis showed that $\mathrm{CC} 5, \mathrm{CC} 15$ groups harboured both cap5 and cap8 while $\mathrm{CC} 152$ harboured only cap5 and $\mathrm{CC} 1$ did not harbour any capsular gene. Also, 16 isolates harboured genes for intracellular adhesion proteins (icaA, icaC, icaD) which play a significant role in biofilm formation (Arciola et al., 2001) and are frequently identified among clinical isolates. All isolates except isolates belonging to $\mathrm{CC} 1$ showed to harbour clfA and $c l f B$ (clumping factor $\mathrm{A} / \mathrm{B}$ ). These are genes that allow $S$. aureus to sustain and survive in the anterior nares (Sivaraman et al., 2009)

Another interesting finding is the presence of $s a k$ (staphylokinase gene), sak was present in $28.6 \%$ of the pig isolates from this study. SAK plays a role in the establishment of infections in humans (Nguyen and Vogel, 2016) and 70\%-90\% of sak has been reported in humans (Luedicke et al., 2010; Monecke et al., 2007a; 2009), $10 \%$ of cattle isolates (Monecke et al., 2007b) and in $48.89 \%$ of camel isolates (Monecke et al., 2011). The presence of sak gene in this study contradicts the report that $S$. aureus strains from veterinary sources commonly lack SAK production (Katayama et al., 2013; Resch et al., 2013). However, the presence of $s a k$, lukD+lukE and scn among some of the isolates suggests a possible human-pig transmission.

Among other genes, agrII, capsule type 5, clfA and clfB were most common. The higher incidence of agrII may be associated with the virulence potential of $S$. aureus (Cheung et al., 2011). This observation is in agreement with the report of Song et al. (2015) who reported that agr-type identified is important among $S$ aureus strains as this locus regulates the synthesis of virulence determinants DNA microarray analysis showed that $\mathrm{CC} 5, \mathrm{CC} 15$ groups harboured both cap 5 and cap 8 while $\mathrm{CC} 152$ harboured only cap5 and $\mathrm{CC} 1$ did not harbour any capsular gene (Table 1). Also, 16 isolates harboured genes for intracellular adhesion proteins (icaA, icaC, icaD) which play a significant role in biofilm formation (Arciola et al., 2001) and are frequently identified among clinica isolates. Furthermore, the presence of $s d r C$ and $s d r D$ in this study is in tadem with the report of $\mathbf{L i u}$ and $\mathbf{Y u}$, (2015) who reported that these genes are associated with MSSA isolates. These genes are known to promote both bacterial adherence to surfaces and biofilm formation (Liu and Yu, 2015). All isolates except isolates belonging to $\mathrm{CC} 1$ showed to harbour clfA and clfB (clumping factor $\mathrm{A} / \mathrm{B}$ ). These are genes that allow $S$. aureus to sustain and survive in the anterior nares (Sivaraman et al., 2009).

\section{CONCLUSION}

The use of microarray in this study provides first insight into the population structure, virulence factor profiles and carriage of antibiotic resistance genes among $S$. aureus from pigs at slaughter. Despite the few number of $S$. aureus isolates used in this study, it was still difficult to compare our data with other reports due to limited reports on the use of microarray to analyze the gene content 
of isolates from pigs and other animals within Africa so as to understand host specificity of some of these virulence factors of $S$. aureus. Also, the DNA microarray assay provided rapid assessment of the virulence potential of the $S$. aureus strains. An increased attention should be allotted to research involving food animals so as to have insight into the population structure of $S$. aureus isolates in animals in Africa.

Acknowledgement: We thank the abattoir personnel for their cooperation during the collection of samples. Our utmost thanks goes to Dr A.R Larasen of the National Center for Antimicrobial and Infection Control, Statens Serum Institut, Copenhagen, Denmark for providing the laboratory space and Christiana Bleis for her technical support in the course of the laboratory analysis.

CONFLICT OF INTEREST: The authors declare that they have no conflict of interest.

\section{REFERENCES}

Adesokan, H. K., Akanbi, I. O., Akanbi, I. M., \& Obaweda, R. A. (2015). Pattern of Antimicrobial usage in livestock animals in south-western, Nigeria: The need for alternative plans. Onderstepoort Journal of Veterinary Research, 82, 1-6. http://dx.doi.org/10.4102/ojvr.v82i1.816

Arriola, C. S., Guere, M. E., Larsen, J., Skov, R. L., Gilman, R. H., Gonzalez, A E., \& Silbergeld, E. K. (2011). Presence of methicillin-resistant Staphylococcus aureus in pigs in Peru. PLoS One, 6(12):e28529. http://dx.doi.org/10.1371/journal.pone.0028529

Bauer, A.W., Kirby, W.M., Sherris, J.C. and Truck, M. (1966). Antibiotic susceptibility testing by a standard single disk method. Journal of Clinical Pathology, 455, 493-496. https://doi.org/10.1093/ajcp/45.4 ts.493

Bazzi, A. M., Rabaan, A. A., Mahmoud, F., \& Al-Tawiq, J. (2015). Prevalence of Panton Valentine Leukocidin-Positive Methicillin Susceptible Staphylococcus aureus Infections in a Saudi Arabian Hospital. Journal of Infection and Public Health. http://doi.org/10.1016/j.jiph.2015.01.010

Breurec, S., Fall, C., Pouillot, R., Boisier, P., Brisse, S., \& Diene-Sarr, F. (2011) Epidemiology of methicillin-susceptible Staphylococcus aureus lineages in five major African towns: high prevalence of Panton-Valentine leukocidin genes. Clinical Microbiology and Infection, 17(2), 160-165. http://dx.doi.org/10.1111/j.1469-0691.2010.03219.x

Bryston, J., Podkowik, M., Bania, J., \& Schubert, J. (2015). Distribution of enterotoxin genes in Staphylococcus aureus isolates from pork and pigs. Medycyna weterynaryjna, 71(6):341-344.

Cheung, G.Y., Wang, R., Khan, B. A., Sturdevant, D. E., \& Otto, M. (2011) Role of the accessory gene regulator agr in community-associated methicillinresistant Staphylococcus aureus pathogenesis. Infection and Immunology, 79 1927-1935. http://dx.doi.org/1110.1128/1A11.00046-11

Egyir, B., Guardabassi, L., Nielsen, S. S., Larsen, J., Addo, K. K., Newmane, M J., \& Larsen, A. R. (2013). Prevalence of nasal carriage and diversity of Staphylococcus aureus among inpatients and hospital staff at Korle Bu Teaching Hospital, Ghana. Journal of Global Antimicrobial Resistance, 1, 189-193. https://doi.org/10.1016/j.jgar.2013.05.006

Eko, K. E., Forshey, B. M., Carrel, M., Schweizer, M. L., Perencevich, E. N. \& Smith, T. C. (2015). Molecular characterization of methicillin-resistan Staphylococcus aureus (MRSA) nasal colonization and infection isolates in a Veterans Affairs hospital. Antimicrobial Resistance and Infection Control, 4, 10 14.

Fall, C., Abdoulaye, S., Vincent, F., Moustapha, N., Mbacke, S., Federic, L., \& Sebastien, B. (2012). Epidemiology of Staphylococcus aureus in pigs and farmers in the largest farm in Dakar, Senegal. Foodborne Pathogens and Diseases, 9, 962-965. http://dx.doi.org/10.1089/fpd.2012.1197

Frana, T. S., Beahm, A. R., Hanson, B. M., Hanson, J. M., Kinyon, L. L., Layman, L. A., Karriker, A. R., \& Tara, C. S. (2013). "Isolation and characterization of methicillin-resistant Staphylococcus aureus from pork farms and visiting veterinary students," PLOS ONE, 8:e53738. http://dx.doi.org/10.1371/journal.pone.0053738

Goerke, C., Esser, S., Kümmel, M., \& Wolz, C. (2005). Staphylococcus aureus strain designation by agr and cap polymorphism typing and delineation of $a g r$ diversification by sequence analysis. International Journal of Medical Microbiology, 295, 67-75. http://dx.doi.org/10.1016/j.ijmm.2005.01.004

Gordon, R. J., \& Lowy, F. D. (2008). Pathogenesis of methicillin-resistan Staphyloccocus aureus infection. Clinical Infectious Diseases, 46, 350-359. http://dx.doi.org/10.1086/533591

He, W., Chen, H., Zhao, C., Zhang, F., Li, H., Wang, Q., Wang, X., \& Wang, H (2013). Population structure and characterisation of Staphylococcus aureus from bacteraemia at multiple hospitals in China: association between antimicrobial resistance, toxin genes and genotypes. International Journal of Antimicrobial Agents, 42, 211-219. http://dx.doi.org/10.1016/j.ijantimicag.2013.04.031 Katayama Y., Baba, T., Sekine, M., Fukuda, M., \& Hiramatsu, K. (2013). Betahemolysin promotes skin colonization by Staphylococcus aureus. Journal of Bacteriology, 195, 1194-1203.
Liu, H., Lv, J., Qi, X., Ding, Y., Li, D., Hu, L., Wang, L., \& Yu, F. (2015). The carriage of the serine-aspartate repeat protein-encoding $s d r$ genes among Staphylococcus aureus lineages. The Brazillian Journal of Infectious Diseases, 19, 498-502. http://dx.doi.org/10.1016/j.bjid.2015.07.003

Luedicke, C., Slickers, P., Ehricht, R., \& Monecke, S. (2010). Molecular fingerprinting of Staphylococcus aureus from bone and joint infections European Journal of Clinical Microbiology Infectious Disease, 29, 457-463. http://dx.doi.org/10.1007/s10096-010-0884-4

Momoh, H. A., Kwaga, J. K. P., Bello, M., Sackey, A. K. B., \& Larsen, A. R (2018). Antibiotic resistance and molecular characteristics of Staphylococcus aureus isolated from backyard-raised pigs and pig workers. Tropical Animal Health and Production, 50, 1565-1571. http://dx.doi.org/10.1007/s11250-0181596-5

Monecke, S., Ehricht, R., Slickers, P., Wernery, R., Johnson, B., Jose, S., \& Wernery, U. (2011). Microarray-based genotyping of Staphylococcus aureus isolates from camels. Veterinary Microbiology, 150, 209-314. https://dx.doi.org/10.1016/j.vetmic.2011.02222.001

Monecke, S., Kuhnert, P., Hotzel, H., Slickers, P. \& Ehricht, R. (2007a) Microarray-based study on virulence-associated genes and resistance determinants of Staphylococcus aureus isolates from cattle. Veterinary Microbiology, 125, 128-140.

Monecke, S., Luedicke, C., Slickers, P. \& Ehricht, R. (2009). Molecular epidemiology of Staphylococcus aureus in asymptomatic carriers. European Journal of Clinical Microbiology Infectious Disease, 28, 1159-1165 http://dx.doi.org/10.1007/s10096-009-0752-2

Monecke, S., Slickers, P., Ellington, M., Kearns, A., \& Ehricht, R. (2007b). High diversity of Panton-Valentine leucocidin-positive, methicillin-susceptible isolates of Staphylococcus aureus and implications for the evolution of communityassociated MRSA. Clinical Microbiology Infection, 13, 1157-1164 http://dx.doi.org/10.1111/j.1469-0691.2007.01833

Nguyen L. T., \& Vogel, H. J. (2016). Staphylokinase has distinct modes of interaction with antimicrobial peptides, modulating its plasminogen-activation properties. Scientific reports, 6, 31817-31822.

Resch, G., Francois, P., Morisset, D., Stojanov, M., Bonetti, E. J., Schrenzel, J., Sakwinska, O., \& Moreillon, P. (2013). Human-to-bovine jump of Staphylococcus aureus CC8 is associated with the loss of a beta-hemolysin converting prophage and the acquisition of a new staphylococcal cassette $\begin{array}{llll}\text { chromosomes. } & \text { PLos } & \text { ONE, e58187. }\end{array}$ http://dx.doi.org/10.1371/journal.pone.0058187

Sabat, A. J., Budimir, A., Nashev, D., Sá-Leão, R., van Dijl, J. M., Laurent, F. Grundmann, H., \& Friedrich, A. W. (2013). Overview of Molecular Typing Methods for Outbreak Detection and Epidemiological Surveillance. Eurosurveillance, 18, 20380-20385.

Shaker, Amr, Aboshanab, Khaled, Mabrouk, A., Mohammed \& Hassouna, N. (2014). Plasmid-carried macrolides target site modification erm and efflux $\mathrm{msr}$ genes in some Staphylococcus spp. from lower respiratory tract infected patients. Archives of Clinical Microbiology, 5(5), 1-4

Shittu, A., Oyedara, O., Abegunrin, F., Okon, K., \& Raji, A. (2012) Characterization of methicillin-susceptible and-resistant staphylococci in the clinical setting: a multicentre study in Nigeria. BMC Infectious Diseases, 12, 286 290. http://dx.doi.org/10.1186/1471-2334-12-286

Sivaraman, K., Venkataraman, N., \& Cole, A. M. (2009). Staphylococcus aureus nasal carriage and its contributing factors. Future Microbiology, 4, 999-1008. http://dx.doi.org/10.2217/fmb.09.79

Smith, T. C., Gebreyes, W. A., Abbey, M. J., Harper, A. L., \& Forshey, B. M. (2013). Methicillin-resistant Staphylococcus aureus in pigs and farm workers on conventional and antibiotic-free swine farms in the USA. PLOS One, 8: e63704. https://doi.org/10.1371/journal.pone.0063704

Song, M., Yalong, B., Jie, X., Michelle, Q.C., Chunlei, S., \& Xianming, S. (2015). Genetic diversity and virulence potential of Staphylococcus aureus isolates from raw and processed food commodities in Shanghai. International $\begin{array}{lllll}\text { Journal of } & \text { Food } & \text { Microbiology, }\end{array}$ http://dx.doi.org/10.1016/j.ijfoodmicro.2014.11.020

Svara, F. \& Rankin, D.J. (2011). The evolution of plasmid-carried antibiotic resistance. BMC Evolutionary Biology, 11, 130-133. 